\title{
1. Conceptualizing China as an international actor
}

The chief purpose of theory is to abstract out the non-essential variables so that the interaction of the essential ones can be perceived in fullest clarity. (Glenn Snyder) ${ }^{1}$

At the outset, a basic question needs to be asked: Why does it matter how we conceptualize China? It matters because of the important point that concepts are not neutral. They are based on particular theoretical understandings of the world, and critically, have very real world policy implications. The trading state in the literature on China's reform-era literature is a liberal state. ${ }^{2}$ Accordingly, analytical attention is invested in distinctly liberal concerns such as maximizing cooperation through comparative advantage and gains from trade. ${ }^{3}$ In contrast, in the realist view, the economic sphere is a political arena where power politics operates, ${ }^{4}$ and can just as easily generate conflict as cooperation. ${ }^{5}$ Also, identity state and social state theorists utilize the concept of socialization in different ways from the instrumentalism of realists. ${ }^{6}$ In respect to the innenpolitik perspective, admittedly, as realist theory has evolved, there has developed a greater appreciation that domestic type approaches can complement structural level analysis. ${ }^{7}$ But there remains a substantial difference between realists and innenpolitik analysts on how international politics is interpreted. ${ }^{8}$ Analysts' conceptual differences matter greatly. Let us explore the differences in how China has been conceptualized.

\section{CONCEPTUALIZING CHINA}

\section{Trading State}

At face value, the case for viewing China as a trading state is a strong one. China's trade has grown at an annual rate of 15-17 percent for almost 30 years. ${ }^{9}$ In 1982, exports and imports accounted for 15 percent of China's Gross Domestic Product (GDP). By 2013, trade constituted 50 percent of its GDP. ${ }^{10}$ In the period from 1978 to 2012, China's economy grew at an exponential rate. At the onset of the reform era, it constituted 2 percent of the global economy. ${ }^{11}$ By 2018, that figure had expanded to 12.4 percent, the highest in the world, and 
ahead of the second-placed US. ${ }^{12}$ According to the World Bank's 2030 report, China is now the world's largest exporter, the largest manufacturer. ${ }^{13}$ As one International Monetary Fund report noted: 'Few countries have so obviously gained from integration into the open world trading system as China, its growth coinciding with its ascendancy as an exporter and manufacturer. ${ }^{14}$ In positional terms, this rise has occurred in the context of relative US decline as a trading state compared to China. ${ }^{15}$ A 2019 analysis of International Monetary Fund data by the Sydney-based Lowry Institute reveal that in 2018, 128 out of 190 states traded more with China than the US; 90 countries traded more than twice as much with China as the US. ${ }^{16}$ In 2001, the year China joined the World Trade Organization, 152 states traded more with the US than China. ${ }^{17}$

Perhaps not surprisingly, research on international perceptions of China's role in world politics has found that it is in the economic sphere where Chinese influence is perceived as being strongest. ${ }^{18}$ And, given the profound impact that China has had on the international trading system (and vice versa), it is not surprising that the trading state viewpoint occupies a prominent place in the literature. The basic concept was introduced by Richard Rosecrance in the mid-1980s, to analyse the strategies of a variety of states in the international system including: Germany, Hong Kong, Japan, Singapore, South Korea, and Taiwan. ${ }^{19}$ The core claim is that increased trade significantly reduces the incentive for conflict, of which war is the most serious manifestation. ${ }^{20}$ Thus, Rosecrance maintains that in a world of trading states 'the incentive to wage war is absent ... for war disrupts trade and the interdependence on which trade is based.' ${ }^{21}$ Indeed, a trading state is defined as one that does not seek to conquer territory. ${ }^{22}$ For Rosecrance, in the nuclear age, 'wars of territorial expansion are not only dangerous, they are costly and threatening to both sides. Much more tenable is a policy of economic development and progress sustained by the medium of international trade. ${ }^{23}$ Logically, this process can evolve to the point where capitalist states establish a capitalist peace. ${ }^{24}$

The Chinese foreign policy literature has picked up on the trading state idea. Thus, Ikenberry contends that while the international system benefits from China's economic dynamism, 'the existing trading system is also valuable to China, and increasingly so. Chinese economic interests are quite congruent with the current global economic system ... that China has enthusiastically embraced and thrived in. ${ }^{25}$ Similarly, David Zweig posits that 'no state has benefitted more than China from trade liberalization and globalization. ${ }^{26}$ China is portrayed as learning quickly from the Soviet Union's failed experiment with the military route to success in world politics. ${ }^{27}$ China's rise is also viewed as part of a larger and 'ongoing revival of the East Asian tradition of relying primarily on the economic sources of power. ${ }^{28}$

The regional dimension of China as a trading state is particularly impressive. David Shambaugh has identified expanded economic relations between 
China and its Asian neighbors as one of the four pillars of a more activist and successful regional policy. ${ }^{29} \mathrm{He}$ observes that 'the most noteworthy dimension of China's new engagement with the Asian region is in the economic domain. ${ }^{30} \mathrm{~A}$ robust trend is identified of 'growing interdependence and cooperation among both states and non-state actors - with China increasingly at the centre of this activity. ${ }^{31}$ The figures for China's economic interdependence with Asia are impressive. If anything, these have grown since Shambaugh's study, which was published in 2005 , and relied on figures available for the year 2003. In 2003, trade between China and the entire Asian region amounted to US $\$ 495$ billion. ${ }^{32}$ By 2010, China's trade with its top six Asian trading partners alone was worth US $\$ 867$ billion. ${ }^{33}$ For 2017 , the latest year for which World Bank figures are available, if we include the US as an Asia-Pacific state, trade with the region amounted to US $\$ 1428$ billion. ${ }^{34}$ Looking at the data in a slightly different way drives home the point. In 2003, six of China's top trading partners were from the Asia-Pacific region. ${ }^{35}$ By 2010, this number had increased to eight. ${ }^{36}$ The figures are holding steady. In 2017, eight of China's top ten trading partners were from the region. ${ }^{37}$ For trading state theorists, the implications of these figures are transformative. Erich Weede has discussed China's rise in the context of the emergence of an extended period of 'capitalist peace' for Asia. ${ }^{38}$ Weede's analysis has led him to conclude that 'from an international trade perspective, all of East Asia has recently become a Chinese sphere of influence. ${ }^{39}$

\section{Analysing the Role of Trade in Chinese Foreign Policy}

As an empirical matter, in trade terms, contemporary China and East Asia are highly interdependent. Whether it follows that China is most cogently conceptualized as a trading state is quite another matter. The critical weakness of trading state theory is its apolitical nature, with its attendant inability to satisfactorily account for how states that are locked in a relationship of deep interdependence nevertheless experience high levels of conflict.

Deep economic ties between the China, the US, and Taiwan did not forestall the Taiwan Straits' crisis of 1995-96, where the US was required to mobilize the Seventh Fleet to prevent further escalation of the dispute. ${ }^{40}$ At the time, the US-China trade volume stood at an impressive US $\$ 57$ billion. ${ }^{41}$ In 1996, the US was China's second largest trading partner, and China was the US's fourth largest trading partner. ${ }^{42}$ Ironically, it was the Taiwanese leader Lee Tenghui, who at the time was leading an entity that is often characterized in the literature as a trading state, ${ }^{43}$ who played the catalyst role in the crisis. ${ }^{44}$ Trading state theorists are at a loss to explain this pivotal event in the post-Cold War era. In fact, the event does not even merit a mention in Rosecrance's 1999 analysis of 
how the trading state (of which Taiwan is discussed extensively as an example) has allegedly morphed into a virtual state. ${ }^{45}$

In contrast, an excellent starting point to understand the Taiwan Straits crisis is to appreciate Betts's and Christensen's point that since it is 'both sides in a political dispute that have a stake in not overturning profitable economic integration,' therefore, 'mutual dependence makes political conflict a game of chicken. ${ }^{46}$ It might be argued that this critique of the trading state perspective is missing the point, since the actual use of force represents a relatively rare episode in relations, and that the US has since returned to a robust trading relationship with China. That said, one can just as well turn the argument on its head and point to persistent friction across a spectrum of issues in the US-China relationship since 1995-96. Indeed, the record of post-Cold War US-China relations covered in Chapter 3 reinforces this exact point.

What if the US-China relationship is in some way atypical of most bilateral relationships, and thus an inappropriate one to test trading state theory against? What about China's relations with states that are not in its sights as a prospective peer competitor, as the US arguably is? Japan is increasingly interdependent with China, yet the effect of economic interdependence in moderating conflict is much weaker than is often claimed.$^{47}$ More specifically, Japan is regularly China's second largest trading partner, yet as the analysis in Chapter 4 demonstrates, the Chinese continue to view Japan as one of their principal security concerns (and vice versa). ${ }^{48}$ It might be contended that historical issues make the Sino-Japanese case a unique one, and, therefore, a better test of the theory would involve China's relations with some other East Asian state. A review of the Sino-South Korean case also reveals high levels of tension over various issues - ranging from history to territorial issues and more recently, the Terminal High Altitude Area Defense (THAAD) issue despite high levels of economic interdependence. ${ }^{49}$ This is particularly the case as Seoul has come to appreciate the limits and/or unwillingness of Beijing to restrain Pyongyang. ${ }^{50}$

Reviewing these examples, it would appear that politics significantly conditions the effects of trade, rather than vice versa. An emphasis on a political understanding of Chinese foreign policy helps us to appreciate why trade and other economic-related activity is regularly politicized. ${ }^{51}$ This is due to realist concerns with using economics for strategic gains ${ }^{52}$ and minimizing vulnerability. ${ }^{53}$ Manifestations of these dynamics include China bearing economic losses for political ends, ${ }^{54}$ and using its superior political position to leverage Hirschmanesque political and economic benefits. ${ }^{55}$ It also includes smaller states seeking to diversify their trade sources, to reduce exposure and vulnerability to China. ${ }^{56}$ This dynamic is particularly relevant in asymmetrical relationships, which are a characteristic of many of China's relationships. ${ }^{57}$ 


\section{Identity State}

A significant theme in the literature on Chinese foreign policy is the focus on the concept of identity to explain China's international interactions. Perhaps the most prominent articulation of the identity state perspective is David Kang's argument in China Rising and a variety of closely related writings. Kang contends that fears over China's rise are 'empirically unfounded. ${ }^{58}$ Rather, it is claimed that there is a shared regional understanding about 'China's preferences and limited aims. ${ }^{59}$ In this view, present-day Asian actors have reverted to pre-colonial-era conduct that allegedly identified Chinese regional hegemony with stability ${ }^{60}$ In this interpretation, China is seen as 'increasingly becoming the regional hierarch,' displacing the US. ${ }^{61}$ What is driving these dynamics? For Kang, 'it is interests and identity, not power that are the key variables in determining threat and stability in international relations. ${ }^{62}$ Notwithstanding the reference to interests in the argument, it is the convergence of national identities in post-Cold War Asia that does the heavy lifting in the analysis. ${ }^{63}$ On this basis, Kang generates insights into the region's future international relations. Thus, he predicts a regional dynamic toward 'accommodation' of China's central position, rather than a posture of balancing against it. ${ }^{64}$

In sharp contrast to Kang's analysis, for other analysts, it is precisely aspects of China's identity that is generating concerns in respect to China's rise. Thus, Shambaugh identifies a variety of Chinese state identities that are linked to particular discourses among Chinese academics. ${ }^{65}$ Shambaugh's analysis suggests that China possesses 'multiple identities and a schizophrenic personality.' ${ }^{66}$ In a related vein, for Rozman, it is 'the evolution of Chinese national identity ${ }^{67}$ that explains China's post-2007 'assertive behavior. ${ }^{98}$ In this view, ideology plays an extremely important role in Chinese identity. ${ }^{69}$ According to Rozman, a 'new ideological synthesis' or 'amalgam' was promoted by the Chinese Communist Party's propaganda department, gaining momentum by $2007 . .^{70}$ In one sense, the use of the identity concept by analysts to explain variation in China's international behavior is easy to understand. Kang was writing during an early 'honeymoon' period of China's rise, while Shambaugh's and Rozman's analysis were written after it became clear that the earlier identity analysis was too focused on cooperative aspects in Chinese policy. That said, the limitations of identity analysis merit highlighting.

\section{The Challenges of Using Identity as a Variable: Selection Bias, Power, and Anarchy}

The first issue concerns methodology. The above-mentioned works are characterized by the methodological problem of selecting the dependent variable. ${ }^{71}$ 
Thus, individual analysts have used identity to explain either conflict or cooperation. Their particular explanations therefore cannot explain variance in outcomes in Chinese foreign policy across the breadth of the reform era. It might be asked, why is this such an important issue? A theory establishes a relationship between variables. For a theory to be methodologically sound, covariance between variables has to be established. ${ }^{72}$ However, by selecting on the dependent variable, since only a causal claim for conflict or cooperation is established, the theory is not set up to explain the full range of the data.

As an example of this point, let us examine Kang's analysis writings on China's reform-era foreign policy. Kang contends that Chinese identity explains China's East Asia policy since the late 1970s. But he provides little evidence that China's identity has changed sufficiently to account for the empirical record of Chinese assertiveness policy since 2009. Certainly, as evidenced in a chapter that was published in 2010 , there is slightly more circumspection about Chinese foreign policy. ${ }^{73}$ But Kang is a long way from acknowledging that China's identity has changed to the extent that it can account for the increased assertiveness in post-2009 Chinese foreign policy. Of course, he could conceivably fall back on his second variable, Chinese interests, to explain policy. ${ }^{74}$ But that tact is also problematic since we are then in the realm of variables emphasized in realist theory, which are categorically rejected by Kang as inadequate in their capacity as single variables, independent of identity, to explain Chinese foreign policy and Asian international relations. $^{75}$

Second, even if a test for identity theory is properly constructed to explain covariation, it is unclear how China's identity can change so quickly in identity-based analyses, with such significant consequences for Chinese policy. It is highly revealing that analysts who just a few years ago were positing identity as a reason for optimism are now citing precisely that same variable as reasons for pessimism. Shambaugh mentions in 2005 that China is gradually shedding its 'identity of historical victim. ${ }^{76}$ Yet in 2011, identity is cited by as the key reason for an increasingly assertive Chinese Asia policy. ${ }^{77}$ Could China's identity have changed from 2005 to 2011? This seems highly unlikely. If identity is so malleable, it draws our attention to the fact that the claims on behalf of identity may be a case of spurious causation, masking the operation of more fundamental variables which remain unspecified.

A third point that merits our attention is that by focusing so heavily on the identity-related discourses, our attention is diverted from asking ourselves about what is causing the rise of these particular discourses, which are the most important, and why this is the case. The fact that analysts and policy-makers are more interested in China's state identity rather than of Cambodia or Laos suggests that attention needs to be focused on the operation of material power. Yet, this is obscured in the identity-based analysis we have reviewed. The point 
is not to dismiss the claims that identity theory may have some utility in our understanding of China's international behavior. It is to suggest that the theory and basic concepts will require more rigorous interrogation. ${ }^{78}$ Even after this is done, we would still need to pay significant attention to non-identity-related political and material forces emphasized by realist theorists.

\section{Social State}

A third approach conceptualizes China as a social state which has been deeply socialized by participation in international institutions. Thus, Mark Beeson contends that 'China's evolving foreign policies reflect the cumulative influence of greater engagement in international institutions. Put differently, Chinese elites have been "socialized" into a new externally-derived normative order in ways that have affected the PRC's long-term international behavior. ${ }^{79}$ A similar perspective is reflected in Alastair Johnston's Social States. Johnston's argument is that China's participation in international institutions since the 1980s has activated socialization processes of mimicking, social influence, and persuasion. ${ }^{80}$ This has led to a 'convergence of preferences and beliefs and conformist behavior' between Chinese officials and their counterparts. ${ }^{81}$ These processes have the potential to transform Chinese inter-state behavior. In a separate study, Johnston has evaluated China's compliance with five major international normative regimes, specifically, sovereignty, free trade, national self-determination, human rights, and non-proliferation and arms control. ${ }^{82}$ China emerges in this analysis as a state that is quite comfortable with the US-constructed international order. ${ }^{83}$

Inspection of social state theorists' arguments raises two questions. First, and perhaps most critically, as an empirical matter, what evidence is there that China has been socialized in ways that social state theorists contend? A review of Chinese behavior at a variety of the international multilateral institutions over the last decade is instructive. Chinese foreign policy at various institutions reveals little, if any, operation of socialization dynamics in moderating realpolitik behavior. ${ }^{84}$ One of the more interesting revelations in the WikiLeaks cables is that of the US Ambassador to China Jon Huntsman reporting that numerous state representatives had complained to him about Chinese assertiveness in furtherance of its interests at institutions ranging from the Copenhagen Climate Change Summit to the East Asian Summit (EAS). ${ }^{85}$

More specifically, there has been a very clear Chinese pattern of blocking discussion of critical issues which impinge on its interests. ${ }^{86}$ To cite two examples, at the 2012 Association of Southeast Asian Nations (ASEAN) summit in June, and the EAS in November, China successfully weighed on Cambodia, the host on both occasions, to neutralize debate over the South China Sea dispute. ${ }^{87}$ In the face of this challenge, ASEAN's much-advertised consensus 
model has broken down. More generally, since 2004, there have been delays in obtaining consensus at ASEAN meetings because states have been analyzing how China will react, even as word is being fed back to Beijing in respect to individual states' positions on issues China has taken a stand on. ${ }^{88}$ In fact, in reviewing China's post-Cold War-era policy on the territorial disputes in the South China Sea, a strong case could be made that China has been systematically using institutions as a political tool to defer the resolution of territorial disputes, even while it pursues a divide and rule policy and accumulates a greater capability to resolve the disputes in its favor.

Second, even if we were to accept for the sake of argument that China has been socialized by states in an institutional context, there is still the question of how strong the socialization effect is. The record of Chinese foreign policy outlined in this book suggests a very weak socialization effect. More generally, the topic of China's socialization strategies represents an under-researched area of study. As it develops, it is plausible that attention will turn to China, in its capacity as a socializer. Socialization attempts by China are inextricably linked to its inherent attractiveness. ${ }^{89}$ Here it is highly likely that China, in its capacity as a socializer, has been less successful in this task than has been suggested in the social state literature, precisely because of genuine threat perceptions from regional actors, as emphasized in realist theory. ${ }^{90}$

\section{Innenpolitik State}

A fourth conceptualization of China in the literature is that it is an innenpolitik state, where domestic factors are critical in explaining outcomes in foreign policy. ${ }^{91}$ In analysing China's 'suboptimal ${ }^{92}$ and 'destabilizing ${ }^{93}$ post-2008 foreign policy, ${ }^{94}$ Ross has argued that we need to focus on Chinese nationalism. In Ross's view, 'nationalism, rather than security, is driving China's naval ambition. ${ }^{95}$ In this perspective, 'naval nationalism is one manifestation of "prestige strategies," whereby governments seek international success to bolster their domestic popularity. ${ }^{96}$ Ross's larger argument is a domestic one, where deteriorating economic conditions have led to rising nationalism. Thus, Ross contends that 'nation-wide economic instability, the erosion of the party's performance-based legitimacy, and declining party control over society, the dissemination on the internet of broad-based and increasingly strident nationalist sentiment [has] increased the salience of nationalism in policy making. ${ }^{97}$

Was China, as Ross claims, in a state of economic decline and associated instability in 2009-10? The broad measures of China's economic growth and inflation are well established. Here, it is hard to square the facts with Ross's claims that the Chinese economy was the cause of a spike in Chinese nationalism. Quite the contrary. The World Bank has reported that China's economic 
growth in 2009 was 9.2 percent and 10.4 percent in $2010 .{ }^{98}$ Even if one adopts a slightly broader time-frame, China's economic growth in 2008 was 9.6 percent, and 9.3 percent in 2011. ${ }^{99}$ What about inflation? During 2009, inflation was actually -0.7 percent, while in 2010 it was 3.3. percent. ${ }^{100}$ Adopting a broader time-span reinforces the point. China's inflation in 2011 was an admittedly high 5.4 percent, but fell to 2.7 percent in 2012 and 2.6 percent in $2013 .{ }^{101}$ It is a stretch to say that this is evidence of deteriorating economic circumstances. This is not to overlook evidence of Chinese nationalism, only to point out that the phenomenon is arguably a supplementary factor in Chinese foreign policy, and arguably determined by other more realist considerations, as laid out below.

\section{Neorealist State}

A final perspective on China as an international actor is represented by neorealist theory. Neorealism was originally conceived as a structural theory of international theory of international politics, to explain general patterns in international politics such as the recurrence of war. ${ }^{102}$ There are a few versions of neorealism, all of which share certain core assumptions. The point of departure for neorealists is that states operate in a defined environment, which is referred to as the structure of the international system, and where the organizing principle of the system is anarchic. This simply means that there is no centralized authority that governs the international system. The central actors in the system are states which in the first instance are concerned with their own survival. ${ }^{103}$ This generates a reliance by each state on its own efforts ${ }^{104}$ and an attendant concern with relative gains. ${ }^{105}$ States are focused on minimizing vulnerability in both economic and non-economic issue areas. ${ }^{106}$ Alliances or partnerships may be formed if there is a sufficient convergence of interests. ${ }^{107}$ Alliances are an external balancing instrument. This is distinct from internal balancing, which refers to a state's efforts to enhance its own security through economic development and military modernization. ${ }^{108}$ As the theory has evolved, neorealism has also been used to explain the foreign policies of states. ${ }^{109}$

From this basic model, there have emerged three major variants of neorealist theory. These are offensive realism, defensive realism, and neoclassical realism. In the offensive realist view, exemplified in the scholarship of John Mearsheimer, China's rise portends a bleak future for East Asia and beyond. ${ }^{110}$ As China's relative power rises, ${ }^{111}$ it will simultaneously be feared, particularly by its neighbors, and fearful of other states. ${ }^{112}$ Critical in this respect is the economic sphere. In Mearsheimer's view, as the Chinese economy grows, it will 'almost certainly translate its economic might into military might and make a run at dominating Northeast Asia.' ${ }^{113}$ China will 'attempt to become 
a regional hegemon in Asia'114 and 'push the United States out of Asia.' ${ }^{115}$ In response, the US will oppose Chinese policy and likely treat China the way it did the Soviet Union. ${ }^{116}$ In fact, Mearsheimer views China's rise as being even more dangerous than the four states (Wilhelmine Germany, Imperial Japan, Nazi Germany, the Soviet Union) it faced down in the twentieth century, since China is potentially far more powerful than any of them. ${ }^{117}$ It is important to note that Mearsheimer is not predicting a reckless Chinese foreign policy, nor an imminent Sino-US war, though he does expect consistent security competition that could culminate in war under certain specific conditions. ${ }^{118}$ Mearsheimer is principally focused on a 'future world where the balance of power has shifted sharply against the United States, and where China is in roughly the same economic and military league as the United States.' ${ }^{119}$

Three points can be made about Mearsheimer's offensive realist viewpoint. First, on straightforward realist grounds, it is far from clear that Mearsheimer's conclusions about China's ability to achieve regional hegemony are as inevitable as he claims. For reasons related to geography, the deck is stacked against powerful rising continental powers like China from achieving regional hegemony. ${ }^{120}$ This is particularly the case in the early twenty-first century, which would require Beijing to dislodge the US from its post-1945 position of maritime supremacy in East Asia. These geographic realities are not trivial, and explain the historical rarity of a successful naval power projection policy by continental states. It is not without reason that the naval theorist Alfred Mahan has observed that 'history has conclusively demonstrated the inability of a state with even one continental frontier to compete in naval development with one that is insular, ${ }^{121}$ although of smaller population and resources. ${ }^{122}$

Moreover, the costs are not limited to a failed naval policy. Jonathan Kirshner points out that the strategy of making a bid for regional hegemony, exemplified by Napoleonic France, Imperial Japan, Wilhelmine Germany, and Nazi Germany, has demonstrably led to regime destruction. ${ }^{123}$ Indeed, even Mearsheimer acknowledges the rarity of successful bids for regional hegemony, with the US serving as the exception rather than the rule. ${ }^{124}$ Despite these geographic disadvantages, in a post-Cold War context of relatively weak neighbors and rising Chinese power, Beijing may indeed persist in its attempt to achieve regional maritime supremacy. ${ }^{125}$ But it needs to be recognized that China faces a far more significant challenge in succeeding than Mearsheimer's analysis suggests.

Second, it is also important to place China's rise in a larger structural context. Mearsheimer views China's rise as moving the region toward a 'war-prone' and 'unbalanced multipolar system.' ${ }^{126}$ However, it is just as, if not more, convincing to describe China's rise as moving us toward a stable US-China bipolar regional system, albeit one with frictions. ${ }^{127}$ In this picture, 
China has assumed a more influential position in mainland Asia, with the US dominant over maritime Asia. ${ }^{128}$

Third, to the extent that Mearsheimer relies on the security dilemma concept to explain conflict as China rises, it is unpersuasive. ${ }^{129}$ As Snyder observes of Mearsheimer's account of great power politics, notwithstanding the emphasis on the security dilemma concept, 'there is a lot of security competition, but little security "dilemma". ${ }_{130}$ As explained in greater detail in our discussion of the security dilemma concept below in defensive realism, a security dilemma requires the various participants in a relationship to be genuine security maximizers. And, as our review of China's relations with the various states in the chapters in this book highlights, at least one of the states has deliberately pursued a policy reflecting a revisionist posture toward the regional status quo.

A second version of neorealism is represented by the defensive realist view, which is adopted by a number of prominent analysts of Chinese foreign policy. ${ }^{131}$ Defensive realists share with their offensive realist kin the view that states must anticipate conflict, even outright war. ${ }^{132}$ However, they are sensitive to the fact that offensive policies carry significant risks, ranging from lost gains from cooperation to outright diplomatic and military loses. ${ }^{133}$ Defensive realists emphasize the gains from inter-state cooperation ${ }^{134}$ and have a preference for defensive behavior. ${ }^{135}$ In this perspective, while there are a variety of values that states may strive for, they must, in the first instance, seek to maximize their security. ${ }^{136}$ Defensive realists do not accept the offensive realist assumption that the maximization of relative power and the pursuit of security are synonymous. Instead, defensive realists are sensitive to the fact that the pursuit of power maximization strategies can easily backfire, exacerbating security dilemma dynamics. ${ }^{137}$ The security dilemma is the central concept for defensive realism and the focus of our critique. ${ }^{138}$

Three elements are essential for the security dilemma to operate: anarchy (which leads to uncertainty about states' present and future intentions, fear, and the attendant requirement for self-help); a lack of malign intentions ${ }^{139}$ on the part of the states involved; ${ }^{140}$ and some accumulation of power. ${ }^{141}$ The security dilemma is an unintended phenomenon, but it bears noting that genuine conflicts of interest can drive security dilemma dynamics between states. ${ }^{142}$ Also, while the security dilemma is principally regulated by objective material factors, subjective psychological factors often play a role in exacerbating the situation. ${ }^{143}$ A critical point to note is that a security dilemma can only operate between defensive realist states. Thus, the security dilemma concept is conditional. It is not applicable to all conflicts. ${ }^{144}$

Since security maximization and the related concept of the security dilemma occupy a central role in defensive realism, our assessment of the theory's utility for understanding China's post-1978 foreign policy rests on whether China is a security maximizer. The question of what exactly constitutes 
security maximization has not received sufficient attention. Waltz, the most prominent proponent of defensive realism, stresses the importance of security maximization as 'the highest end,' linking it to 'survival. ${ }^{145}$

To the extent that we can identify a common core in what constitutes a definition of security maximization, as Schweller notes, it is clearly associated with defending the status quo. ${ }^{146}$ Thus, security dilemma politics reflects the dynamics of status quo states that nonetheless find themselves in heightened conflict when they would have preferred stability. This is the meaning of 'defensive' in the security dilemma literature - states seek to 'defend' their security within the strategic status quo, with actions that nonetheless undermine the security of the other state. The empirical record clearly does not support security dilemma interpretation of Chinese foreign policy in the post-1978 era. To be sure, at times, China's regional policy has clearly exhibited a concern with defending or sustaining the regional status quo. The defensive status quo dimension of Chinese policy is exemplified in Chinese policy toward the Soviet-Vietnamese alliance from 1975 to the end of the Cold War. In this instance, Vietnamese policy was clearly revisionist. At other times, Beijing has clearly sought to revise the status quo which other states are defending. This is reflected in China's post-Cold War South China and East China Seas policy. ${ }^{147}$ In these examples, the protagonists have not been uniformly status quo states, as security dilemma theory requires.

A final realist perspective on China's foreign policy is advanced by Denny Roy, who adopts a security dilemma-based neoclassical realist view. ${ }^{148}$ As China rises, Roy finds the forces mitigating conflict to be less powerful than those that accentuate it. ${ }^{149}$ The critical question is why? For Roy, China's rise will generate strategic tensions on two grounds. The first is generic, and applies to all rising great powers. As China rises, its interests will expand and it will seek to establish a regional sphere of influence for standard neorealist security and power considerations. Regional states will either submit or resist. More likely, they will resist and security dilemma dynamics will intensify. ${ }^{150}$ The US will invariably be drawn into the fray.

Roy adds a twist with his second rationale for strategic tension. This pertains to China's 'unique characteristics. ${ }^{151}$ Here, he places significant weight on perceptions, which are shaped by 'idiosyncratic factors, ${ }^{152}$ specifically, history and public opinion. Roy's contention is that the past matters because unlike other previous rising powers, China is a 'returning power' with a long history as a regional hegemon. ${ }^{153}$ This is important because it heightens the intensity of Chinese grievances and sense of entitlement, increasing the likelihood of conflict. As far as public opinion is concerned, Roy contends that 'strategically short-sighted domestic political pressure may force the Beijing leadership to act against its own wishes and pursue risky foreign policies. ${ }^{154}$ That said, he is careful to note that peacefully integrating a rising China is "not 
impossible, ${ }^{155}$ even if it will still lead to a 'net reduction in security for most of the world. ${ }^{156}$

In evaluating Roy's arguments, two points should be highlighted. First, Roy identifies the central role of the security dilemma concept in exacerbating conflict between China and regional states. ${ }^{157}$ But as noted in our review of the security dilemma concept in defensive realist theory, for the concept to apply, both parties in a relationship must be status quo powers. ${ }^{158}$ China's post-1978 policy in East Asia is best characterized not through security dilemma dynamics, but rather, the dynamics of power projection, which in turn, reflect state interests and increasing power capabilities.

Second, Roy contends that China's interpretation of its history, notably its 'century of shame,' roughly from the onset of the first Opium War in 1839 to the Chinese Communist Party's victory in the Chinese Civil War in 1949, is an acute problem for its external relations. Yet, a careful reading of Roy's narrative raises important questions as to the actual impact of history on foreign policy. Roy effectively critiques historically deterministic arguments offered to explain why China will be a benign great power. He convincingly points to an impressive history of war-making in China's history, exemplified during the Yuan and Qing dynasties. ${ }^{159}$ However, when Roy moves to emphasize an interpretation of China's history as a source of conflict, the analysis swings to the other extreme of the historical determinism pendulum. It is not clear why history necessarily privileges either of these two positions. More likely, the role of history is indeterminate, and depends on China's capabilities and interests.

\section{CONCLUSION}

Concepts constitute the basis for theory, and theory is essential to understand world politics, of which China's rise is arguably one of - if not the - critical long-term development. It is therefore critical that we begin with a correct conception of China. As Robert Jervis advises in a different context, 'if one starts with misleading concepts, the more complete and thorough the reasoning, the stranger and more confused are the results. ${ }^{160}$ This chapter has identified and interrogated a variety of influential concepts used to understand China as an international actor. These include understandings of China as an identity state; a social state; a trading state; an innenpolitik state; an offensive realist state, a defensive realist state, and a neoclassical realist state. We will now attempt to show, through three case studies, how a revised neorealist model focused on state interests and power capabilities can illuminate our understanding of China's international behavior in the post-1978 era. 


\section{NOTES}

1. Glenn Snyder, 'Deterrence and Power,' Journal of Conflict Resolution 4, no. 2 (1960): 174.

2. Indeed, trading state theorists contrast their view with the realist one. Thus, trading state advocate Richard Rosecrance notes the existence of 'two fundamentally different modes of organizing international relations,' namely, a territorial system and a trading system. These represent two extremes on a continuum. In the territorial system, which Rosecrance calls 'the military-political world, nations are ranged in terms of power and territory from the greatest to the weakest.' By contrast, in the trading world 'nations are differentiated in terms of function.' Trading states 'seek to improve their position ... within a context of accepted interdependence.' They also recognize that 'they can do better through internal economic development sustained by a worldwide market for their goods and services than by trying to conquer and assimilate large tracts of land.' Richard Rosecrance, The Rise of the Trading State: Commerce and Conquest in the Modern World (New York: Basic Books, 1986), 16-18, 23-5.

3. For the liberal trading state view of economics, see Rosecrance, Rise of the Trading State, 24-8, 136-62.

4. For the realist view on trade and economics more generally, see Jonathan Kirshner, 'The Political Economy of Realism,' in Unipolar Politics: Realism and State Strategies After the Cold War, eds. Ethan Kapstein and Michael Mastanduno (New York: Columbia University Press, 1999), 69-102; Mark R. Brawley, 'The Political Economy of Balance Power Theory,' in Balance of Power: Theory and Practice in the 21st Century, eds. T.V. Paul, James Wirtz, and Michael Fortmann (Stanford: Stanford University Press, 2004), 76-99; Kenneth Waltz, Theory of International Politics (New York: McGraw-Hill, 1979), 129-60.

5. See Ross's discussion of China's trade relations with Japan and South Korea which reveal the strong operation of realpolitik practices. Robert Ross, 'The Rise of Chinese Power and the Implications for Regional Security Order,' Orbis 54, no. 4 (Fall 2010): 526-7, 537-8.

6. For a realist view of identity, see Robert Jervis, 'Realism in the Study of World Politics,' International Organization 52, no. 4 (1998): 988-9. For a realist view of socialization, see Cameron G. Thies, 'State Socialization and Structural Realism,' Security Studies 19, no. 4 (2010): 689-717.

7. Brian Rathbun, 'A Rose by Any Other Name: Neoclassical Realism as the Logical and Necessary Extension of Structural Realism,' Security Studies 17, no. 2 (2008): 294-321.

8. For illumination on this point, see Krasner's discussion of the bureaucratic model in Stephen D. Krasner, 'Are Bureaucracies Important (Or Allison Wonderland)?' Foreign Policy no. 7 (Summer 1972): 159-79.

9. David Zweig, 'The Rise of a New Trading Nation,' in China, the Developing World, and the New Global Dynamic, eds. Lowell Dittmer and George T. Yu (Boulder: Lynne Rienner, 2010), 39; World Bank and State Council, People's Republic of China, China 2030: Building a Modern, Harmonious, and Creative Society (Washington DC: 2013), 379.

10. Daniel H. Rosen, Avoiding the Blind Alley: China's Economic Overhaul and Its Global Implications (New York: Asia Society, 2014), 146. Accessed September 5, 2020 at https://asiasociety.org/files/pdf/AvoidingtheBlindAlley_FullReport.pdf. 
11. Rosen, Avoiding the Blind Alley, 132, 145.

12. Center for Strategic and International Studies, 'Is China the World's Top Trader?' February 19, 2020, https://chinapower.csis.org/trade-partner/.

13. World Bank and State Council. People's Republic of China, China 2030: Building A Modern, Harmonious, and Creative Society. Washington DC: 2013, 5. Accessed September 5, 2020 at http://documents.worldbank.org/curated/en/ 781101468239669951/pdf/China-2030-building-a-modern-harmonious-and -creative-society.pdf.

14. International Monetary Fund, Country Report No. 11/193, People's Republic of China, Spillover Report for the 2011 Article IV Consultation and Selected Issues (Washington DC: July 2011), 3.

15. On the importance of the positional rivalry in world politics, see Randall Schweller, 'Realism and the Present Great Power System: Growth and Positional Conflict Over Scarce Resources,' in Ethan Kapstein and Michael Mastanduno, eds. Unipolar Politics, 28-68.

16. Alyssa Leng and Roland Rajah, "Chart of the Week: Global Trade Through a US-China Lens,' The Interpreter, December 18, 2019. Accessed September 5, 2020 at https://www.lowyinstitute.org/the-interpreter/chart-week-global-trade -through-us-china-lens.

17. Leng and Rajah, 'Chart of the Week.'

18. Gregory G. Holyk, 'Paper Tiger? Chinese Soft Power in East Asia,' Political Science Quarterly 126, no. 2 (2011): 223-54.

19. Rosecrance, Rise of the Trading State.

20. Rosecrance, Rise of the Trading State, 24-8.

21. Rosecrance, Rise of the Trading State, 24-5.

22. Rosecrance, Rise of the Trading State, 16-17.

23. Rosecrance, Rise of the Trading State, 13.

24. Erik Gartzke, 'The Capitalist Peace,' American Journal of Political Science 51, no. 1 (January 2007): 166-91.

25. G. John Ikenberry, 'The Rise of China and the Future of the West: Can the Liberal System Survive?' Foreign Affairs 87, no. 1 (January/February 2008): 32.

26. Zweig, 'Rise of a New Trading Nation,' 38.

27. Giovanni Arrighi, 'Reading Hobbes in Beijing: Great Power Politics and the Challenge of the Peaceful Ascent,' in Routledge Handbook of International Political Economy: IPE as a Global Conversation, ed. Mark Blyth (London: Routledge, 2009), 163-79.

28. Arrighi, 'Reading Hobbes in Beijing,' 179.

29. Shambaugh notes that 'the most noteworthy dimension of China's new engagement with the Asian region is in the economic domain.' David Shambaugh, 'China Engages Asia: Reshaping the Regional Order,' International Security 29, no. 1 (Winter 2004-05): 83.

30. David Shambaugh, 'Return to the Middle Kingdom? China and Asia in the Early Twenty-First Century,' in Power Shift: China and Asia's New Dynamics, ed. David Shambaugh (Berkeley: University of California Press, 2005), 36.

31. Shambaugh, 'China Engages Asia,' 65.

32. Shambaugh, 'China Engages Asia,' 83.

33. World Integrated Trade Solution (WITS), 'China Trade Statistics,' November 22, 2019. See entry for China at the World Bank's database. Accessed September 5, 2020 at https://wits.worldbank.org/CountryProfile/en/CHN.

34. WITS, 'China Trade Statistics.' 
35. WITS, 'China Trade Statistics.'

36. WITS, 'China Trade Statistics.'

37. WITS, 'China Trade Statistics.'

38. Erich Weede, 'The Capitalist Peace and the Rise of China: Establishing Global Harmony by Economic Interdependence,' International Interactions 36, no. 2 (2010): 206-13.

39. Weede, 'Capitalist Peace,' 209.

40. Robert Ross, 'The 1995-96 Taiwan Strait Confrontation: Coercion, Credibility, and the Use of Force,' International Security 25, no. 2 (Fall 2000): 87-123.

41. Wayne M. Morrison, China-US Trade Issues (Washington DC: Congressional Research Service, 2011), 2. Accessed September 5, 2020 at https://china.usc.edu/ sites/default/files/article/attachments/China-US\%20Trade\%20Issues\%202011 \%20Jan.pdf.

42. United States Department of Transportation, 'Top 25 Trading Partners of the US in Merchandise Trade: 1995-2011.' Accessed November 22, 2019 at http:// ops.fhwa.dot.gov/freight/freight_analysis/nat_freight_stats/docs/12factsfigures/ table2 8hist.htm.

43. Rosecrance, Rise of the Trading State, 24.

44. Bruce J. Dickson, 'Taiwan's Challenge to US Foreign Policy,' in Assessing the Lee Teng-hui Legacy in Taiwan's Politics, eds. Bruce J. Dickson and Chen-min Chao (New York: M.E. Sharpe, 2001), 264-86.

45. Richard Rosecrance, The Rise of the Virtual State: Wealth and Power in the Coming Century (New York: Basic Books, 1999).

46. Richard Betts and Thomas Christensen, 'China: Getting the Questions Right,' National Interest 62 (2000/2001): 22. Emphasis added.

47. For the claim that economic interdependence dynamics operate strongly in Sino-Japanese relations, see Richard Katz, 'Mutual Assured Production: Why Trade Will Limit Conflict Between China and Japan,' Foreign Affairs 92, no. 4 (July/August 2013): 18-24. For the case that economic interdependence operates weakly in the relationship, see He Yinan, 'Ripe for Cooperation or Rivalry? Commerce, Realpolitik, and War Memory in Contemporary Sino-Japanese Relations,' Asian Security 4, no. 2 (2008): 162-97.

48. Michael Pillsbury, China Debates the Future Security Environment (Washington DC: National Defense University Press, 2000), 107-53; Hiroko Tabuchi, 'Japan Warns of China and North Korea as Security Threats,' New York Times, July 9, 2013. Accessed September 5, 2020 at https://www.nytimes.com/2013/07/10/ world/asia/japan-warns-of-threats-from-china-and-north-korea.html.

49. Jae Ho Chung, Between Ally and Partner: Korea-China Relations and the United States (New York: Columbia University Press, 2007), 78-83, 100-2; Matt Stiles, 'Upset Over a US Missile Defense System, China Hits South Korea Where It Hurts - in the Wallet,' Los Angeles Times, February 28, 2018. Accessed September 5, 2020 at https://www.latimes.com/world/asia/la-fg-china-south-korea-tourism -20180228-htmlstory.html.

50. See discussion of China's interaction with South Korea in John Pomfret, 'US Steps Up Pressure to Rein in North Korea,' Washington Post, December 6, 2010. Accessed September 5, 2020 at https://www.washingtonpost.com/wp-dyn/ content/article/2010/12/05/AR2010120503513.html.

51. Stephen D. Krasner, 'National Security and Economics,' in National Security Affairs: Theoretical Perspectives and Contemporary Issues, eds. Thomas Trout and James E. Harf (New York: Transaction Books, 1982), 313-28. 
52. Kirshner, 'Political Economy of Realism,' in Unipolar Politics, eds. Kapstein and Mastanduno, 69-102.

53. Kenneth Waltz, Theory of International Politics (New York: McGraw-Hill, 1979), 106.

54. Kirshner, 'Political Economy of Realism,' 73-7.

55. Albert O. Hirschman, National Power and the Structure of Foreign Trade (Berkeley and Los Angeles: University of California Press, 1980); Lloyd Gruber, Ruling the World: Power Politics and the Rise of Supranational Institutions (Princeton: Princeton University Press, 2000).

56. Robert Ross, 'On the Fungibility of Economic Power: China's Economic Rise and the East Asian Security Order,' European Journal of International Relations 25, no. 1 (2019): 310.

57. As highlighted in Brantly Womack, China Among Unequals: Asymmetric Foreign Relationships in Asia (Singapore: World Scientific, 2010).

58. David Kang, China Rising: Power, Peace and Order in East Asia (New York: Columbia University Press, 2007), 10.

59. David Kang, 'Why China's Rise Will Be Peaceful: Hierarchy and Stability in the East Asian Region,' Perspectives on Politics 3, no. 3 (September 2005): 552.

60. Kang, China Rising, 4.

61. Kang, 'Why China's Rise Will Be Peaceful,' 552.

62. Kang, China Rising, 9.

63. Kang, China Rising, 4, 9, 11, 20-1; David Kang, 'Getting Asia Wrong: The Need for New Analytical Frameworks,' International Security 27, no. 4 (Spring 2003): $57-85$ at $66-70$.

64. Kang, China Rising, 4.

65. David Shambaugh, 'Coping with a Conflicted China,' Washington Quarterly 34, no. 1 (2011): 9.

66. Shambaugh, 'Conflicted China,' 21.

67. Gilbert Rozman, 'Chinese National Identity and Its Implications for International Relations in Asia,' Asia-Pacific Review 18, no. 1 (2011): 85.

68. Rozman, 'Chinese National Identity,' 84.

69. According to Rozman, this ideological amalgam consists of three narratives: the strength of Chinese socialism; Sino-centrism and Confucianism as a source of Chinese civilizations' historical superiority; and anti-Westernism, seen in the theme of anti-imperialism and anti-hegemonism, exhibited in attacks on Western civilization. Rozman, 'Chinese National Identity,' 88-90.

70. Rozman, 'Chinese National Identity,' 89.

71. Barbara Geddes, 'How the Cases You Choose Affect the Answers You Get: Selection Bias in Comparative Politics,' Political Analysis 2, no. 1 (1990): 131-50.

72. Arthur Stinchcombe, Constructing Social Theories (New York: Harcourt, Brace \& World, 1968), 33-8.

73. David Kang, 'China's Rise: Intentions, Power and Evidence,' in The Routledge Handbook of Security Studies, eds. Myriam Dunn Cavelty and Victor Mauer (New York: Routledge, 2010), 257-67.

74. Kang, China Rising, 9.

75. Kang, China Rising, 9-11, Kang, 'Getting Asia Wrong,' 58-9.

76. Shambaugh, 'China Engages Asia,' 64.

77. Shambaugh, 'Conflicted China,' 7-27; David Shambaugh, China Goes Global: The Partial Power (Oxford University Press, 2013). 
78. For a rigorous attempt at theorizing the identity concept, see Rawi Abdelal et al., 'Identity as a Variable,' Perspectives on Politics 4, no. 4 (December 2006): 695-711.

79. Mark Beeson, 'Hegemonic Transition in East Asia? The Dynamics of Chinese and American Power,' Review of International Studies 35, no. 1 (2009): 104.

80. Alastair I. Johnston, Social States: China in International Institutions, 1980-2000 (Princeton: Princeton University Press, 2008), xxv, 40-41.

81. Alastair Iain Johnston, 'Treating International Institutions as Social Environments,' International Studies Quarterly 45, no. 4 (2001): 488; Johnston, Social States, 20.

82. Alastair Iain Johnston, 'Is China a Status Quo Power?' International Security 27, no. 4 (2003): 5-56.

83. Johnston, 'Status Quo Power?' 49.

84. Contrast Johnston's comment on realpolitik practices in the following pages: Johnston, Social States, xiv, xxvii.

85. Ewen MacAskill, 'WikiLeaks Cables: Aggressive China Losing Friends Around the World,' Guardian, December 4, 2010. Accessed September 5, 2020 at https:// www.theguardian.com/world/2010/dec/04/wikileaks-embassy-cables-diplomacy -china.

86. As occurred on the South China Sea issue in the East Asian Summit and ASEAN Regional Forum. See Jeremy Page, 'China Resists Sea Debate During Summit,' Wall Street Journal, November 19, 2011. Accessed September 5, 2020 at https:// www.wsj.com/articles/SB10001424052970203503204577039892130094070.

87. Carlyle Thayer, 'ASEAN, China and the Code of Conduct in the South China Sea,' SAIS Review of International Affairs 33, no. 2 (2013): 78; Ben Bland, 'ASEAN Curbs US Regional Security Role,' Financial Times, November 18, 2012. Accessed September 5, 2020 at https://www.ft.com/content/439972e8-3185 -11e2-92f0-00144feabdc0.

88. Joshua Kurlantzick, Charm Offensive: How China's Soft Power is Transforming the World (New Haven: Yale University Press, 2007), 140.

89. Shambaugh, China Goes Global, 207-68.

90. Alice Ba, 'China and ASEAN: Re-navigating Relations for a 21st-Century Asia,' Asian Survey 43, no. 4 (August 2003): 622-47.

91. For a theoretical analysis of innenpolitik arguments, see Fareed Zakaria, 'Realism and Domestic Politics,' International Security 17, no. 1 (Summer 1992): 177-98.

92. Robert Ross, 'China's Naval Nationalism: Sources, Prospects, and the US Response,' International Security 34, no. 2 (Fall 2009), 47.

93. Ross, 'China's Naval Nationalism,' 50.

94. Robert Ross, 'Chinese Nationalism and its Discontents,' National Interest no. 116 (November/December 2011): 45-51; Robert Ross, 'The Domestic Sources of China's “Assertive Diplomac" 2009-10,' in China Across the Divide, ed. Rosemary Foot (New York: Oxford University Press, 2013), 72-93; Ross, 'China's Naval Nationalism.'

95. Ross, 'China's Naval Nationalism,' 46.

96. Ross, 'China's Naval Nationalism,' 50.

97. Ross, 'Domestic Sources,' 80.

98. WITS, 'China Trade Statistics.'

99. WITS, 'China Trade Statistics.'

100. WITS, 'China Trade Statistics.'

101. WITS, 'China Trade Statistics.'

102. Waltz, Theory. 
103. Waltz, Theory, 91-2.

104. This is otherwise known as the self-help principle in the international relations literature. As Waltz argues, 'Self-help is necessarily the principle of action in an anarchic order.' Waltz, Theory, 111.

105. For an introduction to the relative gains debate, see David Baldwin, ed., Neorealism and Neoliberalism: The Contemporary Debate (New York: Columbia University Press, 1993).

106. Waltz, Theory, 106.

107. For discussion of the concept of interests, see Timothy Crawford, Pivotal Deterrence: Third-Party Statecraft and the Pursuit of Peace (Ithaca: Cornell University Press, 2003), 30; Daryl Press, Calculating Credibility: How Military Leaders Assess Military Threats (Ithaca: Cornell University Press, 2007), 25-8; Waltz, Theory, 134.

108. Joseph M. Parent and Sebastian Rosato, 'Balancing in Neorealism,' International Security 40, no. 2 (Fall 2015): 51-86.

109. Colin Elman, 'Horses for Courses: Why Not Neorealist Theories of Foreign Policy?' Security Studies 6, no. 1 (1996): 7-53.

110. John Mearsheimer, The Tragedy of Great Power Politics, Updated Version (New York: W.W Norton \& Company, 2014).

111. Mearsheimer, 364-5.

112. John Mearsheimer, 'China’s Unpeaceful Rise,' Current History 105 (2006): 160, 162.

113. Mearsheimer, Tragedy, Updated Version, 4.

114. Mearsheimer, Tragedy, Updated Version, 375.

115. Mearsheimer, Tragedy, Updated Version, 371.

116. Mearsheimer, Tragedy, Updated Version, 384.

117. Mearsheimer, Tragedy, Updated Version, 388.

118. Mearsheimer, Tragedy, Updated Version, 393-4.

119. Mearsheimer states: 'It is important to emphasize that my focus is not on how China will behave in the immediate future, but instead on how it will act in the longer term, when it will be far more powerful than it is today. My focus is on a future world in which the balance of power has shifted sharply against the US, and where China is in roughly the same economic and military league as the United States. In essence, we are talking about a world in which China is much less constrained than it is today.' Mearsheimer, Tragedy, Updated Version, 362.

120. Christopher Layne, "The "Poster Child" for Offensive Realism: America as a Global Hegemon,' Security Studies 12, no. 2 (Winter 2002/03): 127-8.

121. The Oxford American dictionary defines 'insular' as 'of, or, on an island.' Gordon Carruth et al., Oxford American Dictionary (New York: Avon Books, 1980), 460.

122. Alfred Thayer Mahan, Retrospect and Prospect: Studies in International Relations (Boston: Little, Brown and Company, 1902), 169.

123. Jonathan Kirshner, 'The Tragedy of Offensive Realism: Classical Realism and the Rise of China,' European Journal of International Relations 18, no. 1 (March 2012): 53-75.

124. Mearsheimer, Tragedy, Updated version, 41, 143, 212-13.

125. Robert Ross, 'Nationalism, Geopolitics, and Naval Expansionism: From the Nineteenth Century to the Rise of China,' Naval War College Review 71, no. 4 (2018): 16-50.

126. Mearsheimer, Tragedy, Updated Version, 398. 
127. Robert Ross, 'Bipolarity and Balancing in East Asia,' in Balance of Power, eds. Paul, Wirtz, and Fortmann, 267-304.

128. On the stability of bipolarity, see Waltz, Theory, 161-4.

129. See Mearsheimer, Tragedy, 35-6; Glenn Snyder, 'Mearsheimer's World: Offensive Realism and the Struggle for Security,' International Security 27, no. 1 (2002): 156-7.

130. Snyder, 'Mearsheimer's World,' 156.

131. Charles Glaser, 'Will China's Rise Lead to War? Why Realism Does Not Mean Pessimism, Foreign Affairs,' Foreign Affairs 90 no. 2 (March/April 2011): 80-91; Thomas J. Christensen, 'China, the US-Japan Alliance, and the Security Dilemma in East Asia,' International Security 23, no. 4 (Spring 1999): 49-80; Avery Goldstein, 'A Rising China's Growing Presence: The Challenges of Global Engagement,' in China's Global Engagement: Cooperation, Competition, and Influence in the 21st Century, eds. Jacque Delisle and Avery Goldstein (Washington DC: Brookings, 2017), 14.

132. Waltz, Theory, 112-14.

133. Thus, as Robert Jervis states: 'Wars would be much more frequent ... if they were less risky and costly, and if peaceful intercourse did not provide rich benefits.' Robert Jervis, 'Co-operation Under the Security Dilemma,' World Politics 30, no. 2 (January 1978): 176. See also Charles Glaser, 'Realists as Optimists: Cooperation as Self-Help,' International Security 19, no. 3 (1994-95): 50-90.

134. Tang Shiping, A Theory of Security Strategy for Our Time: Defensive Realism (New York: Palgrave Macmillan, 2010), 20-1.

135. Tang, Theory of Security Strategy, 30.

136. This is the assumption of state behavior most commonly associated with defensive realism. That said, the security maximization assumption is not unique to defensive realists. Offensive realists also recognize this point. They simply go further in holding that states must maximize relative power to maximize their security. See Waltz, Theory, 126-7; Robert Jervis, 'Realism in the Study of World Politics,' International Organization 52, no. 4 (Autumn 1998): 981; Mearsheimer, Tragedy, 35-6. See Tang's discussion in Tang, Theory of Security Strategy, 21-3, 26-7. Beyond the security aim, states can have non-security aims including various degrees of power maximization, positional status, and/or prestige. On variable goals in neorealist thought, see Davide Fiammenghi, 'The Security Curve and the Structure of International Politics,' International Security 35, no. 4 (Spring 2011): 126-54.

137. Tang, Theory of Security Strategy, 21-3.

138. Again, this concept is also present in the analysis of analysts who do not necessarily self-identify as defensive realism. See Mearsheimer, Tragedy, 35-6; Scott W. Harold and Andrew Scobell, 'An Assertive China? Insights from Interviews,' Asian Security 9 no. 2 (2013): 128; G. John Ikenberry and Adam Liff, 'Racing Toward Tragedy? China's Rise, Military Competition in the Asia-Pacific, and the Security Dilemma,' International Security 39, no. 2 (Fall 2014): 52-91; Tang Shiping, 'From Offensive to Defensive Realism: A Social Evolutionary Interpretation of China's Security Strategy,' in China's Ascent: Power, Security and the Future of International Politics, eds. Robert Ross and Zhu Feng (Ithaca, New York: Cornell University Press, 2008), 141-62.

139. As Tang states, 'a lack of malign intentions' is 'the most critical ingredient for identifying whether a situation is a genuine security dilemma.' Tang Shiping, 'The Security Dilemma: A Conceptual Analysis,' Security Studies 18, no. 3 (2009): 
598. Charles Glaser, 'The Security Dilemma Revisited,' World Politics 50, no. 1 (October 1997): 171-201. For a defensive realist analysis of role of intentions in world politics, see David M. Edelstein, 'Managing Uncertainty: Beliefs About Intentions and the Rise of Great Powers,' Security Studies 12, no. 1 (2002), 1-40. For the offensive realist view, see Mearsheimer, Tragedy, 45. For a recent debate on this topic, see Sebastian Rosato, 'The Inscrutable Intentions of Great Powers,' International Security 39, no. 3 (Winter 2014/15): 48-88; Charles Glaser et al., 'Correspondence: Can Great Powers Discern Intentions?' International Security 40, no. 3 (Winter 2015/16): 197-215.

140. When the intentions of one or both sides in a security dilemma change from non-malign to malign, we have a situation of aggression, and the situation is no longer a security dilemma. Tang, 'Security Dilemma,' 617-18.

141. Tang, 'Security Dilemma,' 597.

142. On this point, see Tang, 'Security Dilemma,' 598-603. In making this point, Tang follows Glenn Snyder. Snyder explains that the security dilemma concept 'retains the possibility of interest conflicts and aggressive behavior stemming from overlapping goals.' Glenn H. Snyder, “"Prisoner's Dilemma” and "Chicken” Models in International Politics,' Journal of Conflict Resolution 15, no. 1 (1971): 79.

143. Jervis, 'Cooperation Under the Security Dilemma,' 174-6; Tang, Theory of Security Strategy, 66-70.

144. Robert Jervis, Perception and Misperception in International Politics (Princeton: Princeton University Press, 1976), 75, 80; Tang, 'Security Dilemma,' 594, 603-4. 145. Waltz, Theory, 126.

146. Randall Schweller, 'Neo-realism's Status Quo Bias: What Security Dilemma?' Security Studies 5, no. 3 (1996): 90-121.

147. Nicholas Khoo, 'Fear Factor: Northeast Asia and China's Rise,' Asian Security 7, no. 2 (July 2011): 95-118.

148. Denny Roy, Return of the Dragon: Rising China and Regional Security (New York: Columbia University Press, 2013), 3, 260.

149. Roy, Return of the Dragon, 157, 177.

150. Roy, Return of the Dragon, 3, 260.

151. Roy, Return of the Dragon, 3.

152. Roy, Return of the Dragon, 7.

153. Roy, Return of the Dragon, 3.

154. Roy, Return of the Dragon, 5.

155. Roy, Return of the Dragon, 262.

156. Roy, Return of the Dragon, 262.

157. Roy, Return of the Dragon, 3, 260.

158. Schweller, 'Neo-realism's Status Quo Bias,' 91-2.

159. Roy, Return of the Dragon, 27-9.

160. Robert Jervis, The Illogic of American Nuclear Strategy (Ithaca: Cornell University Press, 1984), 20. 